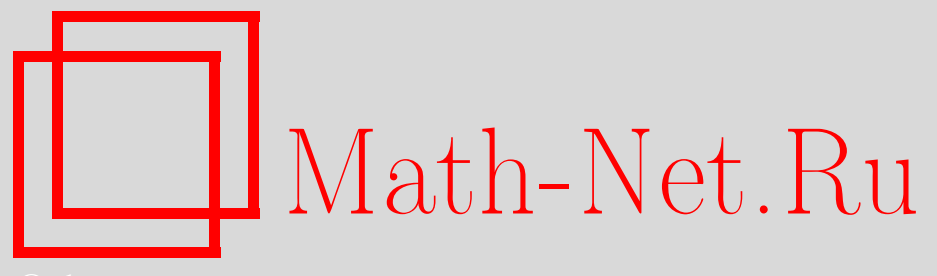

Ю. Н. Радаев, Памяти Дюиса Даниловича Ивлева, Вестн. Сам. гос. техн. ун-та. Сер. Физ.-мат. науки, 2013, выпуск 2(), 9-12

DOI: https://doi.org/10.14498/vsgtu1250

Использование Общероссийского математического портала Math-Net.Ru подразумевает, что вы прочитали и согласны с пользовательским соглашением

http://www.mathnet.ru/rus/agreement

Параметры загрузки:

IP : 54.224 .60 .19

26 апреля 2023 г., 08:39:26

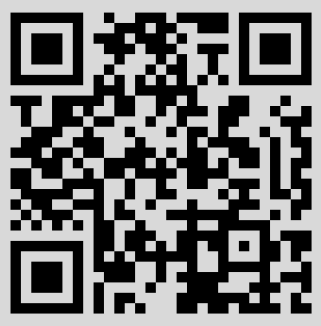




\section{Памяти Дюиса Даниловича Ивлева}

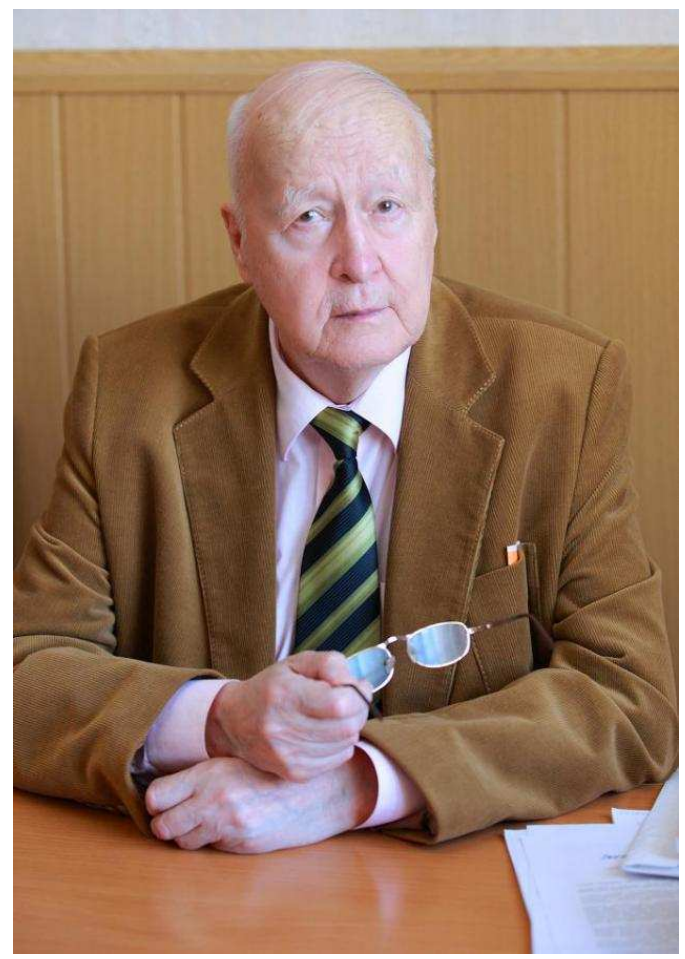

$(09.09 .1930-03.03 .2013)$

3 марта 2013 года на 83-м году жизни скоропостижно скончался выдающийся российский ученый, доктор физико-математических наук, профессор, Заслуженный деятель науки Российской Федерации, член редколлегии журнала «Механика твердого тела» Дюис Данилович Ивлев. Главное в творческой деятельности Д. Д. Ивлева - бескомпромиссное служение научной истине и неустанный поиск на самых передовых рубежах современной науки. Без малого 60 лет его научной и общественной деятельности, выдающиеся научные достижения позволяют причислить Д. Д. Ивлева к категории одного из самых оригинальных мыслителей современной России.

Д. Д. Ивлев родился 6 сентября 1930 г. в г. Чебоксары Чувашской Республики. Его отец - Ивлев Данил Осипович (1905-1969 гг.) - происходил из семьи крестьянина-бедняка, проживавшей в деревне Верхние Сунары Шуматовской волости Ядринского уезда. Сельская комсомольская организация направила его в 1923 г. для учебы на Чувашский рабфак, а затем Д. О. Ивлев был направлен в Московский институт народного хозяйства им. Г. В. Плеханова и обучался там с 1926 по 1931 г. Желая лично участвовать в культурном возрождении Чувашии, получившей в 1920 г. административно-территориальную автономию, он в 1931 г. по направлению ЦК ВЛКСМ вернулся 
в Чебоксары, чтобы преподавать в Чувашском педагогическом институте. Д. О. Ивлев 3 августа 1941 г. был призван в армию и прошел всю войну, закончив её в составе Третьего Белорусского фронта. Данил Осипович с супругой Иулианией Даниловной вырастили двух сыновей Дюиса и Дмитрия и дочь Евгению.

После окончания средней школы в 1948 г. Д. Д. Ивлев покидает Чебоксары и поступает на механико-математический факультет Московского государственного университета им. М. В. Ломоносова, который заканчивает в 1953 г. В 1956 г., после окончания аспирантуры при Институте механики МГУ, он успешно защитил диссертацию «Приближенное решение упругопластических задач методом малого параметра» в совете при МГУ (оппонентами по этой работе выступили В. В. Соколовский и Г. С. Шапиро) и получил ученую степень кандидата физико-математических наук. С февраля 1957 г. по октябрь 1958 г. он работает в должности младшего научного сотрудника Института механики АН СССР. В 1959 г., после защиты диссертационной работы «Пространственная задача теории идеальной пластичности», которая также представлялась в совет при МГУ, Д. Д. Ивлев получает степень доктора физико-математических наук. Оппонентами по докторской диссертационной работе выступили Л. А. Галин, Л. М. Качанов и Г. С. Шапиро.

В октябре 1959 г. Д. Д. Ивлев по приглашению ректора Воронежского университета Б. И. Михантьева приезжает в г. Воронеж. Там он возглавил созданную им в ВГУ кафедру теории упругости и пластичности и выполнил огромную научно-исследовательскую и организационную работу. В 1966 г. Д. Д. Ивлев возвращается в Москву, где сначала работает профессором МВТУ им. Н. Э. Баумана (1966-1970 гг.) и заведует кафедрой высшей математики, а затем (1971-1982 гг.) - заведующим кафедрой высшей математики во Всесоюзном заочном политехническом институте (сейчас Московский государственный открытый университет). Вместе со своими учениками профессорами Г. И. Быковцевым и И. А. Бережным параллельно он активно участвует в создании научной школы механики деформируемого твердого тела в г. Куйбышеве.

В 1982 г. Д. Д. Ивлев возвращается на родину в г. Чебоксары и работает в ЧГУ им. И. Н. Ульянова заведующим кафедрой математического анализа, заведующим кафедрой механики деформируемого твердого тела и деканом физико-математического факультета (1982-1993 гг.). В 1993 г. Д. Д. Ивлев перешел на работу в Чувашский государственный педагогический университет им. И. Я. Яковлева, где до конца жизни заведовал кафедрой математического анализа.

Научные работы Д. Д. Ивлева (всего свыше 300) посвящены механике деформируемого тела, в основном математической теории пластичности. Среди них семь монографий: «Теория идеальной пластичности» (1966); «Теория упрочняющегося пластического тела» (в соавторстве с Г. И. Быковцевым, 1971); «Метод возмущений в теории упругопластического тела» (в соавторстве с Л. В. Ершовым, 1978); «Теория пластичности» (в соавторстве с Г. И. Быковцевым, 1998); «Математическая теория пластичности» (в соавторстве с А. Ю. Ишлинским, 2001); двухтомная монография «Механика пластических сред» $(2001,2002)$; «Предельное состояние деформируемых тел и горных пород» (в соавторстве с Л. А. Максимовой, Р. И. Непершиным, 
Ю. Н. Радаевым, С. И. Сенашевым, Е. И. Шемякиным, 2008). Ряд результатов Д. Д. Ивлева имеет фундаментальный характер для всей механики деформируемого твердого тела.

Основные научные достижения Д. Д. Ивлева связаны с созданием теории трехмерной задачи идеально пластического тела. В этом направлении им была существенно развита математическая теория пластичности А. Ю. Ишлинского (1946 г.), в которой были приняты два уравнения, связывающие главные напряжения, и одно тензорное уравнение перестановочности, эквивалентное, как выяснилось позднее, ассоциированному закону течения на ребре призмы Кулона-Треска. Вектор развития этой идеи, означавший полный пересмотр воззрений, господствовавших в то время, постепенно привёл Д. Д. Ивлева к уравнениям математической теории пластичности гиперболического аналитического типа. Ему впервые удалось выяснить исключительную роль критерия текучести Треска-Сен-Венана: уравнения теории пластического течения на ребрах и гранях призмы Кулона-Треска для напряжений и скоростей имеют гиперболический аналитический тип. Это обстоятельство, указавшее прежде всего на альтернативу эллиптическим уравнениям многочисленных теорий пластичности, позволило распространить на трехмерные течения представление о линиях скольжения, известных из теории плоского деформированного состояния; теория двумерных полей скольжения и поразительные законы, которым они подчиняются, были созданы и открыты Г. Генки и Л. Прандтлем более чем за три десятка лет до трехмерных гиперболических формулировок А. Ю. Ишлинского и Д. Д. Ивлева.

Д. Д. Ивлеву принадлежит исчерпывающий анализ уравнений общей плоской задачи и уравнений теории упрочняющегося пластического тела. Он выполнил исследование кинематики пространственного пластического течения на поверхностях максимальной скорости сдвига. Построил ряд новых автомодельных решений. Им решены пространственные и осесимметричные задачи о вдавливании твердых тел в идеально пластическую среду. В задаче Л. А. Галина о растяжении пластинки с отверстием статическое решение ему удалось дополнить кинематическим.

В последние годы Д. Д. Ивлев активно разрабатывал общую гиперболическую парадигму механики сплошных сред и, в широком смысле, всего естествознания.

Отличительной особенностью научного творчества Д. Д. Ивлева является сочетание прикладного содержания теории пластичности с глубоким и элегантным математическим исследованием гиперболических задач для систем нелинейных дифференциальных уравнений в частных производных, к которым приводит изучение полей напряжений и скоростей деформаций в области пластического течения.

В конце 80-х Д. Д. Ивлев создал в Чебоксарах докторский диссертационный совет по механике деформируемого твердого тела и обеспечивал его функционирование в течении двух десятков лет. Он придал ему качественно новый статус регионального совета, в работе которого участвовали ведущие ученые нашей страны в области механики деформируемых тел и конструкций. Этот совет сыграл исключительно важную роль в подготовке кадров высшей квалификации для многих региональных научных школ. 
Дюис Данилович Ивлев руководил одной из крупнейших научных школ России. В настоящее время она включает около 100 кандидатов и более двух десятков докторов наук, работающих в Москве, Воронеже, Самаре, Владивостоке, Чебоксарах. По отношению к своей научной школе он всегда выступал как ученый и мыслитель, педагог и мудрый наставник.

Дюис Данилович вёл большую общественную работу в Чувашии, часто выступал на страницах региональной печати как яркий публицист. Он является автором ряда оригинальных научно-популярных и публицистических изданий, таких как «Двое в академической лодке, не считая науки», «Мир эллиптический и мир гиперболический», «Короли и академики» и др. До конца жизни он оставался ответственным редактором созданной им естественнонаучной серии журнала «Вестник Чувашского государственного педагогического университета им. И. Я. Яковлева».

Д. Д. Ивлев - член Российского национального комитета по теоретической и прикладной механике, член экспертного совета по математике и механике ВАК РФ, действительный член Национальной академии наук и искусств Чувашской Республики, академик Международной инженерной академии и Инженерно-технологической академии Чувашской Республики, лауреат Государственной премии Чувашской Республики в области науки и техники (2006 г.).

Дюис Данилович Ивлев награжден медалями «За доблестный труд в Великой Отечественной войне 1941-1945 гг.», «50 лет Победы в Великой Отечественной войне 1941-1945 гг.», «60 лет Победы в Великой Отечественной войне 1941-1945 гг.», медалью ордена «За заслуги перед Отечеством» II степени, высшей наградой Национальной академии наук и искусств Чувашской Республики - «Золотой медалью им. И. Я. Яковлева».

Дюис Данилович был строг и точен в науке, доброжелателен в жизни. Все мы глубоко скорбим о постигшей нас тяжелой утрате.

Ведущий научный сотрудник Института проблем механики им. А.Ю. Иилинского РАН, доктор физико-математических наук, профессор Ю. H. Радаев 